\title{
Pierre Fauchard the "inventor" of orthodontics
}

\author{
Julien PHILIPPE
}

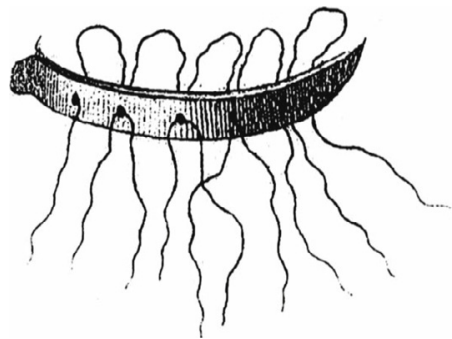

\section{ABSTRACT}

No one before Pierre Fauchard had claimed to be able to move teeth except Celsus who suggested applying finger pressure to a tooth that was erupting in the wrong direction.

Fauchard advised dentists to examine a patient's mouth and occlusion first and then, if necessary, to use one of a number of methods he proposed to "straighten" irregular teeth. The principal device was a "plate," a small segment of thin metal attached to anchor teeth from which force could be exerted on mal-positioned teeth. He uprighted teeth leaning inward by luxation with a "pelican."

The two chapters of his book that were devoted to "straightening" teeth constitute the origin of modern orthodontics.

\section{KEYWORDS}

\section{Pierre Fauchard}

History of orthodontics

Straightening teeth.
Conflicts of interest: none Received: 08-2010. Accepted: 10-2010.

\section{1 - INTRODUCTION}

Did orthodontics exist before the 1728 publication of Pierre Fauchard's book, The Surgeon Dentist or a Treatise on the Teeth?

It is true that Celsus a Roman contemporary of Jesus Christ wrote that when a tooth was erupting in a faulty direction the temporary tooth should be extracted and that corrective finger pressure should be applied to the erupting tooth every day. This is the only known pre-Fauchard reference to tooth straightening. Certainly, Chauliac and Dionis advised dentists to file down teeth 
that were too long and certainly Dupont and Allen thought that teeth could be moved, but no one, except Celsus, had indicated how that could be done. Fauchard wrote that "many people have told me that they have often seen teeth straightened and arranged by the late Mr. Carmeline and by many others." But Carmeline never published.

In other words there was virtually no available documentation on the subject when Fauchard wrote the two chapters of his book that served as the basis for a dental practice of

\section{2 - THE CLINICAL EXAMINATION}

Fauchard did not begin his appointment with a patient by leaping immediately at the tooth that needed straightening, as his contemporaries would have. Instead he introduced the practice of an initial clinical examination, writing, "After having seated the person in an appropriately designed chair, before straightening the teeth that need correction the dentist should first make an examination to determine what situation to place them in; to accomplish this, the dentist must open and close the mouth of the subject upon whom the operation will be performed. First the dentist should examine the teeth that are curved or overly inclined,

\section{3 - FINDING ROOM IN THE ARCH}

Fauchard did not know about, nor even imagine, the possibility of expanding the arch. This procedure was not discovered until 1841, by "straightening" teeth. To use the term orthodontics would be an anachronism. Chapter XXVIII of the first tome of Fauchard's work is entitled "Twelve observations on deformed and poorly arranged teeth" (fig. 1). Chapter VIII of the second volume is entitled "Tortuous (sic) teeth, badly arranged and luxated, instruments and remedies that are useful in operating on them when dentists straighten and stabilize them" (fig. 2). These two chapters, fewer than fifty pages, established the specialty that would later become orthodontics ${ }^{1}$.

check to see if they are longer or larger than the straight teeth that are alongside them. If the tooth to be corrected is longer or larger than it ought to be, it should be filed down to the size of the teeth in good position before any movement is attempted. The dentist should also file down the teeth in the opposing jaw if they have achieved an eruptive height greater than they should have so that in movements of the jaws these teeth will not be thrust against their antagonists that are being straightened." In these few words Pierre Fauchard introduced the idea of occlusal equilibration to the dental profession.

Lefoulon. In order to resolve problems arising from crowding, Fauchard had only two methods at his disposal, extraction or filing, 


\section{CHAPITRE XXVII.} Douze obfervations fur les dents difformes of mal arrangées.

\section{PREMIERE OBSERVATION.}

Sar des dents inégales, gâtées Ė difformes, lefgrelles apres beaucoup de foins, font deverniès très - belles 3 très-bontines.

$\mathrm{F}^{\mathrm{N}}$ 1723. M. Feydean alors âgé Ed'environ quarorze ans, avoir les derits mal arrangées, très-inégales, minces \& pointuës à leur extrétnité, fillonnées, parfemées d'une infinité de petits trous \& de taches noires couvertes d'un grand nombre de tuberofitez \& comme heriffées fur la furface extérieure de leur émail, \& fes gencives éroient fort gonflées. Il avoii la bouche fi défagréable, qu'il ne fembloit pas qu'il eut des dents, ou du moins il ne paroiffoit les avoir que très-mauvaifes. $\mathrm{C} e$ jeune homme farfoit fes études au College du Pleffis

\section{Figure 1}

The first page of chapter XXVII of volume 1, which contains a series of clinical observations.

which we would call today, interproximal stripping.

\section{3 - 1 - EXTRACTION}

"Sometimes crooked teeth cannot be brought into place because there is insufficient available space to accommodate them. In such cases the dentist is obliged to remove one of the crooked teeth in order to distribute space to those that need it.... If, on the other hand, a poorly located tooth

\section{CHA P I R E VIII.}

Des dents tortuës, mal arrangées, di laxées; des inftrumiens ơ des remedes qui forvent $\dot{a}$ ope. ier quard on redre ffe, or quanos on rafermit les dents.

Ors que l'on n'ote point les dents Lde lait dans un tems convenable, elles peuvent faire prendre differentes fgures à celles qui leur fucceedent, les tendre difformes, courbées, panchées in dehors, panchées en dedans, ou panchécs vers les côtez. Il peut encore artiver par-là, que leurs parties laterales fe tournent en dehors, ou qu'elles fe tournent en dedans; ce qui peut caufer plus ou mains de difformité.

Figure 2

The beginning of chapter VIII of volume II, which describes the procedures to be used for "straightening" teeth.

can be placed in line with the others thanks to an existing gap, the dentist can straighten that tooth as much as space allows."

\section{3 - 2 - "FILING" TEETH}

Filing teeth was an operation that Fauchard employed frequently and the long chapter he devoted to it suggested three indications for this procedure: 
- teeth that were crowded could be made slimmer so that they could be properly aligned;

- teeth that were broken and that cut into the cheeks could be smoothed out;

- teeth that were too long could be shortened for esthetic reasons or to equilibrate the occlusion.

Fauchard described in minute detail what position operators should take in regard to their patients and how to place the fingers of the left hand for each group of teeth to be filed. The labial commisures were protected with a "fine cloth". The file should be immersed in hot water before use to protect the patient from feeling a cold shock and the filing should be limited to the enamel layer, which was thinner in children. That is why "there is less danger in filing the teeth of older people". In addition, teeth of older patients are "not as sensitive as the teeth of younger people". "It doesn't often occur that older people find it hard to endure the pain of filing teeth; while sometimes younger people have teeth that are not too sensitive and are able to sit through this operation without feeling pain."

\section{4 - FAUCHARD'S STRAIGHTENING TECHNIQUES ${ }^{2,4,5}$}

\section{$4-1$ - The finger}

"The teeth of young subjects are much easier to straighten than those of adults. That is why it is best first to try to reposition teeth with finger pressure, which should be done many times over the course of the day."

\section{4 - 2 - The wire}

"When the teeth are leaning outside or inside the arch finger pressure alone doesn't suffice to straighten them, the dentist should utilize a wire or waxed silk folded over many times." Fauchard wrote, explaining in minute detail how to derive support from well-aligned teeth, wrapping the wire around several times so that it "embraces" the tooth inclined lingually or buccally. "The dentist activates these wires several times a week and more often if necessary." The wire is also used to close diastemas between incisors and to straighten teeth inclined laterally.

\section{4 - 3 - The gold or silver blade or plate}

"If the teeth are so severely inclined that the wire cannot gain purchase, the dentist should use a thin plate of gold or silver whose length should not exceed that of the two straight teeth between which the crooked teeth are located...this plate should be neither too solid nor too flexible". "The dentist makes two holes on both ends of the plate, and passes a wire through both of them and does the same thing at the other end with a similar wire." In principle, the wire is placed on the side of the mal-positioned tooth, buccally for a tooth leaning buccally and lingually for a tooth leaning lingually. The wires are tied around the anchor teeth situated on each side of the mal-positioned 


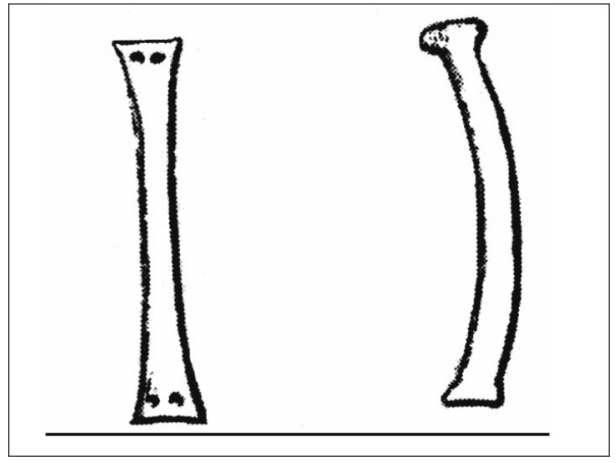

Figure 3

The gold or silver "plate". Its extremities were ligated to well-placed teeth and, in accordance with the needs of each case, exerted pressure or traction, with the aid of a ligature, on crooked teeth.

teeth and, by their pressure, "the sheet will over time straighten the crooked teeth". The dentist might want to replace the holes with indentations. Dentists may also decide to place the sheet buccally to correct a lingually inclined tooth if they fear that with lingual placement "patients would have difficulty in talking or have their tongues made uncomfortable".

Fauchard used this metal sheet for a variety of purposes that he thoughtfully described for his readers.

He employed it, in fact, in much the same way that today's orthodontists utilize arch wires. And Fauchard's successors would continue to employ his thin metal plate for more that a century (fig. 4).

\section{4 - 4 - The pelican (fig. 5)}

"When people are somewhat advanced in age, it takes a fairly considerable amount of time before one can carry out the technique that I just described. This period, which is sometimes quite long, induced me to seek

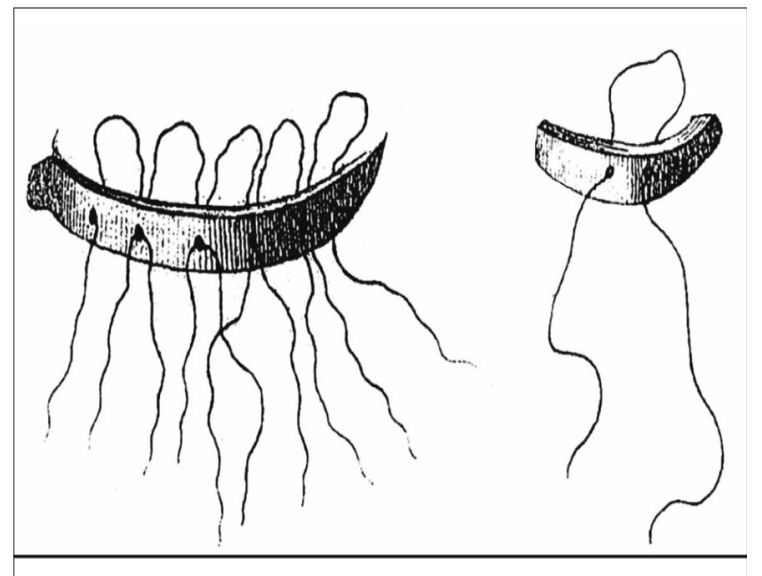

Figure 4

Laforgue used the same plate, only slightly modified, in 1802.

other more expeditious and less inconvenient methods, I found what I wanted with the pelican and straight tweezers land forceps for maxillary incisors). With the help of these two instruments dentists, when they have mastered their use, can, in a moment, accomplish what they are able to do with wire and plate only after a

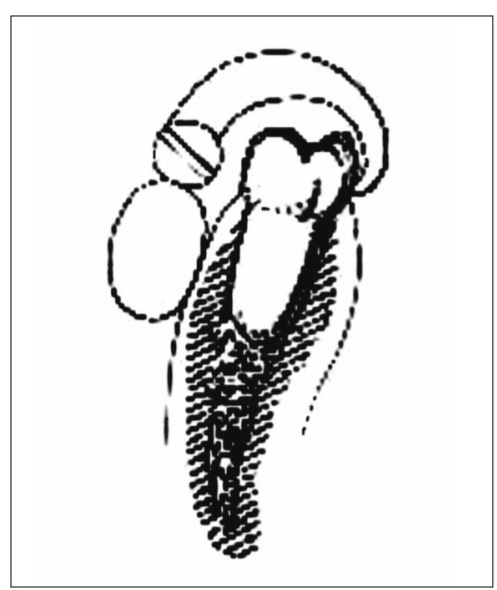

Figure 5

This sketch shows a pelican being used to extract a molar tooth. It is easy to see how the operator could also employ it to upright "teeth inclined inward" by gaining purchase on the buccal gingiva. 
considerable amount of time." But Fauchard added an important caveat:

"the pelican should be used only for teeth that are leaning inward".

In using the pelican orthodontically the operator gained purchase on gingiva and applied pressure from the buccal side of the tooth tilted lingually. This is a risky maneuver and Fauchard warned repeatedly of its dangers. This didn't prevent his "boy" (apprentice) from fracturing the tooth of a "young and beautiful lady" that he was trying to straighten. Fauchard was proud of this procedure that he had invented.

\section{5 - CLINICAL OBSERVATIONS}

Fauchard promised his readers "Twelve observations on deformed and badly arranged teeth" but, in fact, included fourteen in his text. For each observation Fauchard gave the names and ages of the patients, described the state of their dentitions, and explained how he had operated. These observations are extremely expressive, giving an animated idea of how Fauchard performed as a practitioner.

Seven of the cases he treated with the plate and ligature, after having filed or stripped the teeth. The treatments of patients 11 to 14 years old, with an average age of 12 years and 9 months, were completed, on the average, in five weeks.

He treated seven other cases by manipulation of the pelican followed

\section{6 - CONCLUSION}

Pierre Fauchard was the first to demonstrate that the teeth could be

\section{4 - 5 - Retention}

Once they were luxated, teeth were held in place by ligatures or, sometimes, by the application on each side of a lead plate, furnished with a bit of cloth or linen to prevent it from slipping ${ }^{*}$. These plates were affixed by gold wires that went from one to the other between the teeth. It was imported for patients to use mouthwashes: "four ounces of wine with one ounce of rosat honey".

*Described by B. Martin, in $1679^{3}$.

by application of retention wires for one or two weeks. These patients were 9 to 30 years old, with an average age of 18 . The first of these treatments took place in Angers in 1696. It was the only one that required extractions, of four canines "which were placed so far out of the mouth that the incisors were leaning toward the tongue".

Most of these procedures took place between 1719 and 1723. His latest case report, from 1727, described the closing of space after extraction of the root of a broken incisor, following by the equilibration of the uneven and chipped incisal edges of the remaining anterior teeth.

moved with an appliance designed for that purpose. The one that he 
proposed the "plate" was lengthened little by little by Fauchard's successors until it became the arch wire used today ${ }^{3}$.

Fauchard founded orthodontics. So its birthplace was France. The infant science would be fleshed out by Bunon in 1743 and further improved by Bourdet in 1757. The practical application of orthodontics by these
French pioneers became a biological science thanks to the work of the Scottish surgeon and anatomist John Hunter who published two books on the teeth, gingival tissues, and their diseases in 1771 and 1778.

From then on orthodontics gradually spread throughout the world, improving ceaselessly.

\section{REFERENCES}

1. Fauchard P. Le Chirurgien dentiste ou Traité des dents. Paris : Mariette, 1728;vol.I: 309-330, et vol.II : 85-111.

2. Gysel C. Histoire de l'orthodontie. Bruxelles: SBO, 1997.

3. Martin B. Dissertation sur les dents. Paris, 1679.

4. Philippe J. L'orthodontie de Pierre Fauchard. L'Information dentaire du 8 fev. 1996:341345.

5. Weinberger, BW. The History of Orthodontia. Intern Dental J 1916:103-110. 